\title{
BANK OF SEATTLE V. GIDDEN A REPLY TO SAMUEL WILLISTON
}

EDWARD H. WARREN*

I

N THE March number of the Harvard Law Review, ${ }^{x} \mathrm{Mr}$. Williston speaks in several places of the New York case of First Nat'l Bank of Seattle v. Gidden. ${ }^{2}$ He thinks I) that a conditional tender, since it is not a defense for failing to perform an absolute promise to pay, is altogether abortive; 2 ) that the New York courts erred in treating the case as presenting a problem in the modern law of pledge; but 3 ) that the result reached by the court ought to have been reached, even if the case presented a problem in the law of sales.

I deeply regret to say that I differ with him on all three points. So much of my legal gold has come from the Williston mine that I would rather be in a minority of two with him, than in a majority of seven, but with him in the minority. In well over ninety per cent of the questions of law which through the years we have discussed, we have, immediately or ultimately, seen eye to eye both as to the proper result and also as to the reasons for that result. But when we do disagree, either as to result or as to reasons, it never occurs to either of us to cast about for a Delphic "formula" which might serve to conceal our differences. The purpose of this article is to state the reasons which convince me $r$ ) that a conditional tender, though not a defense shield, is a claim (or counterclaim) sword; 2) that the New York court was right in treating the Gidden case as a pledge case; and 3) that if, as Mr. Williston urges, it is a sale case, and not a pledge case, the result cannot be supported by the reasoning presented by Mr. Williston.

It will help to define and clarify the issues to state some preliminary problems:

Problem I.-A promises B to pay B cash for goods to be delivered to A, with intent to pass the title, and $B$ promises to deliver such goods to $A$ with intent to pass the title from $B$ to $A$. It is inherent in such a transac-

* A member of the Harvard Law Faculty, of the New York Bar, and of the Boston Bar.

I Williston, Contractual Relations between Pledgor and Pledgee, 55 Harv. L. Rev. $7^{13}$ (1942).

2 175 App. Div. 563, I62 N.Y. Supp. $3{ }^{7} 7$ (IgI6), aff'd on the opinion below 225 N.Y. 698, I22 N.E. 880 (Igrg). 
tion that $A$ and $B$ have agreed that the goods and the specified amount of cash shall be treated by them as equivalents in value.

In such case, the promises of both $A$ and $B$ are subject to concurrent conditions. A does not make an absolute promise to pay; his promise is conditional-he promises to pay $\mathrm{B}$ if $\mathrm{B}$, as part of the same transaction, delivers. Conversely, $\mathrm{B}$ does not make an absolute promise to deliver; his promise is conditional-he promises to deliver, if $A$, as part of the same transaction, pays.

$\mathrm{A}$ and $\mathrm{B}$ contemplate that the payment and delivery are to be two parts of one transaction. There are concurrent conditions. Each promises to do his part if, but only if, the other does his part, as a part of the same transaction.

Moreover, if A and/or B should thereafter assign his or their rights to a third person or persons ( $C$ and/or $D$ ), neither $C$ (the assignee of $A$ ) nor $D$ (the assignee of $B$ ) would have any greater rights than $A$ or $B$ (as the case may be) had before the assignment. A conditional promise by a promisor cannot be changed into an absolute promise through an assignment by the promisee.

Problem 2.-A promises B to pay B cash in payment of money borrowed, and $A$ also delivers to $B$ some personal property as security for the performance of his promise. This is not a purchase-and-sale case (Problem $I$ ), but a pledge case. In a purchase-and-sale case the parties agree that the goods sold and the specified price are equivalents, exactly balancing each other. But there is no such agreement in a pledge case. The value of the pledge may be, and usually is, larger than the amount borrowed; sometimes it is, or becomes (by reason of events subsequent to the making of the pledge), smaller than the amount borrowed; it will rarely, if ever, happen that the value of the pledge is precisely the same as the amount of the loan.

Now when A borrows, it is thinkable that his promise to pay should be conditional-should have some "if" in it. But lenders have usually been (so far back as the recorded history of mankind goes) very insistent that if money is loaned, the borrower must make an absolute promise to paythat there shall be no "if," "and," or "but" about it. This centuries-old business practice finds an expression in the provision of the Negotiable Instruments Law that a negotiable instrument must contain an "unconditional" promise to pay money. ${ }^{3}$

3 "An instrument to be negotiable must conform to the following requirements: ... . (2) Must contain an unconditional promise or order to pay a sum certain in money." Uniform Negotiable Instruments Act $\S$ I, 5 U.L.A. $3 \times$ (r936). 
Assume that $B$, the lender, requires $A$, the borrower, to make his promise to repay the amount to be'loaned in the form of a negotiable instrument (it is safe to say that this is required in over ninety per cent of such transactions). Without more, $\mathrm{A}$ has made an absolute promise to pay.

But $B$ is unwilling to make an unsecured loan. He requires that $A$ shall deliver defined personal property as a pledge, so that B shall have r) A's absolute promise to repay the amount to be loaned, and 2) a propertysecurity for the performance of that promise. It is elementary that, in every case of pledge, $B$ has a right in personam against $A$, buttressed by a right in rem. Every business day there are thousands of such transactions.

The question narrows to this: did A's giving a pledge somehow have the effect of changing his absolute promise to pay into a conditional promise to pay (a promise to pay if as part of the same transaction $B$ delivers back the security)? There are authorities, fairly stated (but not supported) by Mr. Williston in his article, to the effect that what would unquestionably be an absolute promise by $A$ to pay, if no security had been exacted and given, is demoted into a conditional promise, if security is given. To hold that the giving of security has this demoting, deteriorating effect is indefensible, for the following reasons:

a) In requiring security, $\mathrm{B}$ expected, and $\mathrm{A}$ knew that $\mathrm{B}$ expected, to add something to the strength of his position. The security was to be an addition, and nothing but an addition to the strength of B's position. It was not to have two consequences-one a strengthening consequence, and one a weakening consequence by changing an absolute promise to pay into a conditional promise to pay.

b) It would make the law of negotiable instruments inapplicable to any promise to pay, secured by a pledge. An instrument which on its face is a negotiable instrument would, by reason of the pledge, cease to have its negotiable character at least as to all takers of the instrument who took with notice that it was buttressed by a pledge-and the number of takers having such notice would be large because very frequently the instrument evidencing the promise to pay discloses on its face that it is secured by pledge ("collateral" is the more common expression among businessmen).

That the giving of security does not affect the negotiability of a promise to pay, absolute on its face, is clearly shown by the provisions of Section 5 of the Negotiable Instruments Law, which provides: “. . . . the negotiable character of an instrument otherwise negotiable is not affected by a provision which: I) Authorizes the sale of collateral securities in case the instrument be not paid at maturity...."." If the express spelling-out

45 U.L.A. 69 (1936). 
of the right of a pledgee to make a liquidating sale does not affect the negotiable character of an instrument which on its face is an absolute promise to pay a sum certain in money, it necessarily follows that the giving of security has not destroyed the negotiability of the instrument by demoting the absolute promise to pay into a conditional promise to pay.

c) Moreover, to hold that, where security is given for the performance of a promise to pay money (which would, if no security had been given, have been an absolute promise to pay), A's promise becomes a conditional promise (a promise to pay if as part of the same transaction B delivers back the security) may have consequences which are manifestly unjust. A single example will suffice to demonstrate this. A borrows $\$ 5,000$ from B and delivers security which is worth only $\$ 4,000$. B by tortious conduct loses or destroys the security. Here justice requires that A should pay $B \$ r, \infty 00$, but, if A's promise is conditional upon the return of the security, $\mathrm{B}$ is disabled from maintaining any action against A. A, who should in justice pay $\$ I, \infty$, goes scot-free. Indeed, if $B$ sues, $A$ may successfully defend and mulct $B$ in costs.

Problem 3.-Assuming the same facts as in Problem 2, we now inquire what duty, if any, the pledgee is under. Sometimes the pledgee will expressly promise to return the security, and, in such case, of course, the only problem for the court is to make a just construction of the words employed, whatever they may be. But in the bulk of cases the pledgee makes no express promise, and the question becomes: What, if any, promise by the pledgee as to the return of the security should the law imply?

All the authorities and all the jurists are agreed that some kind of a promise to return the security should be implied by the law; and are also agreed that the implied promise should be, not absolute, but conditional. But what should be the condition (or conditions) of the implied promise by the pledgee to return? That is the question.

Mr. Williston's thought is that the law should imply only a promise by $\mathrm{B}$ that he will deliver the security, if the debt has been paid. My thought is that the law should imply a promise by $B$ that he will deliver the security I) if the debt is matured, and 2) if, concurrently with the delivery by $B$ to $A, A$ pays $B$ the full amount due (which will include interest if the payment is belated and will include both interest and costs if the payment is belated and B has instituted an action against A). In a word, is B's implied promise a promise to deliver after payment, or concurrently with payment?

American authorities on the modern law of pledge all stem from Story, who stated in his treatise on Bailments: 
The pawnee makes himself responsible for all losses and accidents, whenever he has done any act inconsistent with his duty, or has refused to perform his duty. If, therefore, the pawner makes a tender of the full amount of the debt, for which the pawn is given, and the pawnee refuses to receive it, or to redeliver the pledge, the special property, which he has in the pledge, is determined, and he is henceforth treated as a wrong-doer and the pawn is at his sole risk. 5

It is clear, by the common law, that in cases of pledge, if a stipulated time is fixed for the payment of the debt, and the debt is not paid at the time, the absolute property does not pass to the pawnee. This doctrine is, at least, as old as the time of Glanville. If the pawnee does not choose to exercise his acknowledged right to sell, he still retains the property as a pledge, and upon a tender of the debt he may, at any time, be compelled to restore it. 6

Story said that if a tender is refused the pledge interest is determined, and that upon tender, the pledgee may be compelled to restore the pledge. "Tender" and "payment" should be contrasted. Tender connotes that the debtor puts the money, so to speak, right under the nose of the creditor and expresses his willingness that under-the-nose shall become in-thehand, if the creditor concurrently with getting his money into his right hand delivers the security with his left hand. If A tenders the debt, and $B$ has the ability to deliver the security but refuses to do so, then, as a general rule, $\mathrm{B}$ is a converter. And the consequences of the conversion are serious. $B$ becomes an involuntary purchaser of the pledgor's interest. Moreover, the conversion forfeits the pledge interest, and $B$ is therefore changed from a secured creditor into an unsecured creditor. A pledgee will think twice before he exposes himself to such consequences. And it is salutary that this should be so. The law by attaching large importance to tender (as contrasted with payment) protects pledgors from unreasonable conduct by pledgees.

Before we proceed further, it will be helpful to spell out in more detail the law as to the effect of a pledgee's failure to deliver the security upon tender by the pledgor. There are four possibilities:

I) B may incur no liability whatever to $\mathrm{A}$ for failing to deliver. This would be true $a$ ) if the pledge had been destroyed (say, by a fire), or had been lost or stolen, and this sad result was not due to any carelessness or other misconduct on the part of $B ;^{7}$ or $b$ ) if $B$ made a reasonably qualified refusal, as where a third party, $\mathrm{C}$, has made a demand upon $\mathrm{B}$ for the property in question, claiming it as his own, and on such facts the law of the jurisdiction permitted $B$ to file a bill of interpleader (or a statutory action in the nature of a bill of interpleader) against $A$ and $C$, and $B$ only

5 Story, Bailments $\S 34 \mathrm{I}$ (Ist ed. I83 $\mathrm{x}$ ) (italics added).

6 Ibid., at $\$ 346$ (italics added).

7 Ibid., at $\$ \S 33^{2-39}$. 
asks for necessary time to file such bill (or action) $;^{8}$ or $c$ ) if although B has the ability to deliver and makes an absolute refusal to deliver, this refusal is, on the peculiar facts of the case, excusable. Such cases are rare but they do occasionally occur. ${ }^{9}$

2) B may be liable in tort if the destruction, or loss, or theft has been due to his carelessness, but not for that kind of tort which is characterized as a conversion. For centuries it has been settled law that that kind of tort which is called a conversion, with its involuntary-purchase implications, is never constituted by carelessness-the defendant is liable for such damage as the plaintiff has suffered, but he is not an involuntary purchaser. And the damages consequent upon carelessness are often different, and are sometimes widely different, from the damages consequent upon a conversion. ${ }^{\text {o }}$

3) B may be liable for a breach of an express or implied promise to deliver the security upon demand and proper tender. Thus if $B$ has previously disabled himself from delivering the pledge by tortiously transferring it to a third person, such tortious transfer may be (and usually will be) a conversion; but the subsequent failure to deliver what he no longer has the ability to deliver is not a second conversion; it is a breach of contract. And the damages for the breach of contract may be different, and are sometimes widely different, from the damages consequent upon a conversion..$^{\mathrm{Ix}}$

4) B may be liable for a conversion. If $B$ has the ability to deliver and refuses to deliver, ${ }^{12}$ and this refusal is neither justifiable nor excusable, ${ }^{13}$ he is a converter. The damages are involuntary-purchase damages. Moreover, the converter forfeits his rights as pledgee; his right in personam is not destroyed, but it is no longer buttressed by a right in rem. In a word, he is changed from a secured, into an unsecured, creditor. ${ }^{34}$

The lines between these four possibilities should be kept bright. Failure to do that smudges the picture. Such failure has caused much confusion in the decisions, and has made the opinions reek with loose talk. But, after

${ }^{8}$ See the reasoning of the court in Cass v. Higenbotam, 100 N.Y. 248,3 N.E. I89 (I885).

9 See Mires v. Solebay, 2 Mod. 242, 244 (C.P. I676), discussed in Warren, Margin Customers I 26 (194r); McCalla v. Clark, 55 Ga. 53 ( 1875 ), discussed in Warren, Margin Customers I79 (I94r).

so 7 Holdsworth, History of English Law 403, 407, 432 (2d ed. I937); Dearbourn v. Union Nat'l Bank, 58 Me. 273 (1870); Hall v. Boston \& Worcester R. Corp., I4 Allen (Mass.) 439 (I867); Warren, Margin Customers Ir8-23 (r94I).

II See Warren, Margin Customers 238-44, 248-50 (194r).

${ }^{2}$ Cf. possibility 3) supra. ${ }^{23} \mathrm{Cf}$. possibilities I) and 2) supra.

${ }^{{ }_{4}}$ Story, Bailments $\S 34 \mathrm{I}$ (Ist ed. I83I); Warren, Margin Customers I84 (I94I). 
due recognition has been given to possibilities I), 2), and 3), it should be realized that, in the bulk of cases which arise in business transactions, the failure to deliver is a conversion. And the consequences of a conversion are unquestionably serious.

Mr. Williston reasons that because the pledgor has made an absolute promise to pay, therefore payment is a condition precedent to the court's helping him to regain his security. But American courts ever since Story's day have attached great importance to tender. There are scores of cases where a pledgee who has not been paid has had a court render a judgment against him. The fact that the debt has not been paid is given due consideration in measuring damages, but payment is not treated as a condition precedent to the grant of relief to the pledgor.

I am unable to see any way in which Mr. Williston can reconcile with these authorities his contention that the law should imply only a promise by $\mathrm{B}$ that he will deliver the security if the debt has been paid..$^{\mathrm{Is}}$

Moreover, even if so large a body of authority ought not to be accepted as decisive, and the matter were considered de novo, on principle, I submit that the American thought of attaching large importance to tender, as contrasted with payment, deserves cordial support. It is fundamental that law on business matters should accord with the conceptions of businessmen of integrity and experience, unless there is some consideration of public policy which blocks the court from confirming the conceptions of such businessmen..$^{16}$ Attaching large importance to a tender (showing that the pledgor will do his part if the pledgee will do his part at the same time) is in perfect harmony with the conceptions of such businessmen, and I see no consideration of public policy whatever which blocks confirmation.

To reemphasize, the rock-bottom question is as to what should be the condition (or conditions) of the pledgee's implied promise to deliver the security. Mr. Williston contends that the law should only imply a promise by $\mathrm{B}$, the pledgee, to deliver the security if the debt has been paid. I contend that the law should imply a promise by $B$ that he will deliver the security I) if the debt is matured and 2) if concurrently with his delivery to A, the pledgor, A pays him the full amount due.

I have now finished the exposition of the reasons which seem to me to support my contention. I regret that Mr. Williston and I have had to agree to disagree on this, and my regret is profound.

If my contention as to the nature of the implied promise by $B$ is sound, I really do not see that there is anything left worth talking about. When 
a pledgee refuses a tender he usually ${ }^{17}$ acts improperly and the pledgor has a cause of action against him. And under the excellent procedural facilities now available in most jurisdictions there is no obstacle to the pledgor's asserting this cause of action as a claim, or as a counterclaim in an action already begun by the creditor against the debtor, for the debtor's breach of his absolute promise to pay.

I see nothing in the idea that, because a conditional tender is no defense for a breach of the debtor's absolute liability to pay, it follows that it is abortive for all purposes. Just as paper money may not be legal tender in payment of debts due the Government but may be legal tender in payment of private debts, so a conditional tender by a pledgor may be bad for one purpose and yet may be good for another purpose. To distinguish between I) what a creditor may do if the debtor lies down and the creditor is forced to sue, and 2) what a creditor should do by way of cooperation if the debtor offers to do his part is not illogical. It is good sense.

The pith of the matter is that the conditional tender is not good as a defense shield but is good as a claim (or counterclaim) sword.

Let us see where Mr. Williston's contention logically and inevitably leads him. He says:

There is, however, a simple solution of the problem of the contractual rights of the parties that will be just to both. The pledgor, whether he wishes to sue or defend, should pay the amount of the debt into court. If he has the money and could make a conditional tender, payment into court imposes no hardship upon him, and it gives the pledgee the protection to which he is entitled. An objection to this solution is made in Cass v. Higenbotam ${ }^{18}$ on the ground that payment into court would make the creditor absolutely entitled to the money. This indeed, so far from being an objection, is the merit of the procedure. The pledgor, in consequence, immediately becomes entitled to the return of the pledge; and since the money is in the hands of the court, the pledgor by requesting the court to hold it until his own claim has been adjudicated can effect what amounts to an attachment of the fund. ${ }^{x}$

According to this thought, the debtor is to disarm, in the trustful expectation that thereafter the creditor will also be obliged to disarm. This strikes me as an unjustified, one-sided procedure. Moreover, quite apart from the consideration that the protection of the debtor should loom as large with the court as the protection of the creditor, it seems to me clear that the adoption of Mr. Williston's thought would inevitably lead to an increase in the volume of litigation-and a substantial increase. But if the law be that a creditor, who has the ability to deliver and who absolutely refuses to participate in a transaction which is to include the payment of

${ }^{27}$ Page 589 supra.

${ }^{18} 100$ N.Y. 248,3 N.E. 189 (I885).

19 Williston, op. cit. supra note $r$, at 729 . 
his debt in full, will be exposed to the consequences of a conversion, with its involuntary-purchase implications, and will also be changed from a secured into an unsecured creditor, the chances are large that the parties will, by negotiation, adjust whatever differences there may be between them without resort to any court.

Mr. Williston further says:

As a practical matter, a pledgor who wishes to pay his debt and redeem the pledge and who is not confident of the pledgee's ability and readiness to return the pledge on payment, will make a conditional tender. If this is refused, litigation will ordinarily be inevitable, and since the pledgor is assumed to have his money in hand, the necessity of payment into court should not disturb him.20

But I submit that, ordinarily at least, it will disturb him. He wants to recover his security and he wants to recover it now. He does not want to let go his money and then, only after a lapse of time, to get his security, or, if his hope of getting back his security is finally frustrated, to get back his money, less court charges (assuming that such a payment back is permissible under the rules of the court having jurisdiction respecting money paid into court in discharge of an absolute obligation). I do not believe that "litigation will ordinarily be inevitable." Such a thought is unduly pessimistic as to the possibilities of negotiation. So long as the pledgor has cash in his own control which the pledgee wants, the pledgor has a bargaining asset. He is stripped of that bargaining asset as soon as he lets the control of the money pass from him to the court. Most, if not all, pledgors would be disturbed, and seriously disturbed, at losing control of the money while the pledgee is left still in control of the security.

That Mr. Williston offers this payment-into-court as the best solution which occurs to him of the problem we are discussing seems to me to be a very persuasive argument against the adoption of his thoughts.

Now, let no one seek to slur over, or evade, the fact that the problem we are discussing is a very difficult problem. Let us face frankly the fact that there are cross-currents in the thoughts of businessmen. On the one hand, businessmen are strong for the general idea that, if $A$ and $B$ have entered into a contract for their mutual benefit (whether it be for a sale and purchase of goods, or for a lending of money upon security), ${ }^{2 x}$ and each has a duty to the other under the contract, then, if A shows himself ready to do his part and only asks that $B$, at the same time, should do his part, B ought promptly and cordially so to do his part. The instinct for such reciprocity is well-nigh universal and is a normal, wholesome, commendable instinct.

${ }^{20}$ Ibid., at $73 \mathrm{r}$ (italics added).

${ }^{2 x}$ Story, Bailments $\$ \S 289,332$ (Ist ed. 183 I). 
If the contract is one for a sale and purchase of goods (Problem $I$ ), there is nothing to block the way to reciprocity. But if the contract is one for a borrowing of money on security, we begin to feel the pull of a strong cross-current, for businessmen are keen that a debtor's obligation to pay should be absolute.

As the pledgor's obligation to pay is absolute (Problem 2), I concede that at first sight it may appear to be inevitable that the courts should give the pledgee the whip-hand (as Mr. Williston does). Some courts have been so repelled by such a thought that they have adopted the doctrine that an absolute promise to pay is somehow demoted into a conditional promise to pay through the giving of security. I think that such doctrine is clearly indefensible, for the three reasons that have been stated above. ${ }^{22}$ Nevertheless, if I were driven to choose between Mr. Williston's payment-intocourt solution and the concurrent-conditions solution I should go over into the camp of those who lift the banner on which is emblazoned the words "Concurrent Conditions." Two evils, but the latter the lesser evil.

Neither solution of this very difficult problem is, I submit, satisfactory or even justifiable. I have thought about this problem from time to time for more than forty years and have been baffled again and again. It was while pondering over the opinion of the Gidden case that I first caught sight of a light, steering by which I should not be swept upon either Scylla or Charybdis. In that case the court decided that a conditional tender is no defense, but it also said that a conditional tender might be the basis for a counterclaim. I am convinced that the New York court in that opinion evolved the idea that gives a just solution to this problem.

While I am not so bold as to say that to contrast the defense shield with the claim (or counterclaim) sword will always produce justice, yet in every case of which I know or have imagined up to the present time, it seems to me that that thought does point the way to perfect justice between the parties. It has the very important merit of giving protection to the debtor comparable to the protection given the creditor, and thereby to avoid the possibility of any Shylock connotation in our law; it keeps the scales fairly balanced between creditor and debtor; it gives reciprocity, using "reciprocity" in a large sense; it, on the one hand, gives due heed to the instinct for reciprocity which most of us have, and yet, on the other hand, preserves inviolate the desire of businessmen that promises to pay money shall have no weakening "if," "and," or "but" about them.

We now come to the second matter on which I am unable to agree with Mr. Williston. He thinks that the Gidden case presented a question in the ${ }^{22}$ Page 586 supra. 
law of sales, ${ }^{23}$ while $I$ think it presented a case in the modern law of pledge. $^{24}$

Gorman and Co., a corporation (hereinafter called Gorman), was in business in Seattle dealing in canned salmon. On September 2, I9I4, Gorman and the defendant, Gidden, doing business in New York, made a contract of sale and purchase of 5,000 cases of salmon at a specified price, f.o.b. Pacific Coast Terminal shipping points, to be paid for by draft with bill of lading attached, payable on arrival of the goods. So far, the case was a plain Problem $I$ case. ${ }^{25}$ Gidden's promise to Gorman was not an absolute but only a conditional promise. He promised to pay the specified price if, as part of the same transaction, Gorman delivered to him the bill of lading (the commercial equivalent of the cases of salmon).

Then the third legal unit, the First National Bank of Seattle (hereinafter called the Bank) came into the picture. Gorman wanted cash forthwith, and the Bank supplied it on the following terms: the 5,000 cases of salmon were delivered to a carrier, which issued a bill of lading to the order of the Bank; Gorman drew a draft on Gidden for the specified price, indorsed this draft, and handed the draft and bill of lading to the Bank. The Bank thereupon credited Gorman's account with the amount of the draft, which Gorman drew out shortly thereafter.

Note that the transaction between Gorman and Gidden was a merchandising transaction, but that the transaction between Gorman and the Bank was a banking transaction. What was the nature of Gorman's promise to the Bank?

True it is, that Gorman's promise to the Bank, evidenced by its indorsement of the draft, was not, at that time, absolute. Gorman was under the familiar liability of an indorser-he promised to pay the amount of the draft if the drawee failed to meet the draft which was payable forthwith upon the arrival of the salmon in New York. But that was the only condition to Gorman's liability to the Bank. If Gidden failed to meet the draft, Gorman's obligation to pay the Bank would become absolute.

The Bank forwarded the documents to the Irving National Bank (hereinafter called X) for collection. Later, the salmon arrived in New York, and X presented the draft to Gidden, and Gidden refused to pay. It is not expressly stated in the report that $X$ tendered the bill of lading to Gidden at the same time that it presented the draft, but, I submit, the inference that it did so may safely be made-the report expressly states that the goods had arrived before $\mathrm{X}$ presented the draft, and in the argument counsel for Gorman did not contend that there was any justification for Gidden's refusing to pay the draft when first presented.

${ }^{3}$ Page 584 supra.

${ }^{24} 585$.
${ }^{25} 584$. 
This breach by Gidden of the Gorman-Gidden contract naturally disturbed Gorman. Gorman's liability to the Bank was not absolute, and was enforceable forthwith. A representative of Gorman was in, or traveled to, New York and interviewed Gidden. Of course we do not know precisely what occurred at that interview, but in all probability Gorman in no uncertain terms complained of Gidden's default; emphasized that, by reason of that default, the Bank held a sword over Gorman's head; and pressed Gidden "to do something" which would pacify the Bank, and deter it from letting that sword fall.

The upshot of the interview was that Gidden consented to accept the draft, payable at a future date. Gidden wrote on the draft: "Accepted, November 3oth, I9r4. Payable on or before Dec. 23rd, as wanted, at the rate of $\$ 3.40$ and $\$ 3.60$ per case respectively, less $1 \frac{1}{2} \%$, plus $6 \%$ interest from date."

At that time the Bank, not Gorman, owned the draft. What was the nature of Gidden's promise to the Bank, evidenced by that acceptance?

Mr. Williston says (if I may paraphrase his thought): "Once a merchandising transaction, always a merchandising transaction." He says that, when the Bank bought the draft, it simply stood in Gorman's shoes so far as the benefit of Gidden's promise was concerned; and I wish to make it clear that, so far, I entirely agree with him-a conditional promise of a promisor cannot be converted into an absolute promise, through an assignment by the promisee..$^{26}$ But he further says that on November 30 this was still the same old Gorman-Gidden contract, merely modified in some details by the mutual assent of the parties.

I challenge that. I submit that Mr. Williston does not pay due heed to the fact that a banking transaction between Gorman and the Bank (Problem 2) had become inextricably intertwined with the merchandising transactions between Gorman and Gidden (Problem $I$ ). So far as Gorman and the Bank were concerned, it was a plain case of borrowing money on collateral; Gorman's obligation to the Bank had become absolute; Gidden had broken his contract with Gorman (Gidden had had his opportunity to get the salmon by paying the price he had agreed to pay, but had passed up that opportunity); Gorman had appealed to Gidden to do something to pacify the Bank and Gidden now made a new promise direct to the Bank to pay a sum of money to the Bank.

It was not the same old promise; it was not a promise to pay when the goods arrived (for they had long since arrived) but a promise to pay at a future time. The Gorman-Gidden contract had not contemplated an acceptance at all. Even the amount to be paid was not just the same as the

${ }^{26}$ Page 585 supra. 
amount stipulated for in the Gorman-Gidden contract. But these are minor facts. The dominating major new facts were that the Bank already had an absolute promise from Gorman, secured by collateral, that Gorman wanted Gidden to do something to pacify the Bank, and that Gidden put his name on the draft for that purpose.

The natural interpretation of the acceptance transaction was that Gidden had come to the aid of Gorman, and had made a promise to the Bank of the same nature as that of Gorman's promise to the Bank, so that, whereas the Bank had had one string to its bow (Gorman), and had been entitled to treat the cases of salmon (or their commercial equivalent) as collateral against Gorman, it now had a second similar string to its bow (Gidden), and was entitled to treat the cases of salmon (or their commercial equivalent) as collateral against Gidden also.

I feel confident that this was the interpretation of the transaction which the Bank made, and I further feel confident that that is precisely the interpretation which Gidden realized, or at least ought to have realized, was the interpretation which the Bank would make. "Hold your horses awhile; I will back up Gorman."

The view which the New York court took of the nature of the promise evidenced by the acceptance is harmonious with this view. It said: "The bill of lading and warehouse receipt subsequently substituted for it were held by plaintiff as collateral security for the payment of the draft, which it had cashed for Gorman \& Co. It was the ordinary transaction of collateral to secure the payment of a bill of exchange-collateral security and nothing else." 27

I submit that the court was abundantly justified in making that interpretation of the transaction between Gidden and the Bank (not Gorman), and that such interpretation was in accord with the interpretation which most, if not all, experienced businessmen would make.

On December 23, Gidden sent a representative to $\mathrm{X}$ with a certified check for the amount due, for the purpose of honoring his obligation and obtaining the warehouse receipt (which had been substituted for the bill of lading). When the representative of Gidden reached the bank the draft and warehouse receipt could not be found, and the representative of Gidden, after waiting some time, left without paying the draft or formally tendering the certified check in payment of it. About twenty minutes to four in the afternoon of the same day the draft and receipt were found and a representative of $\mathrm{X}$. telephoned to Gidden's office, asked for Gidden,

\footnotetext{
${ }^{27}$ First Nat'l Bank of Seattle v. Gidden, $x 75$ App. Div. 563, 566, I62 N.Y. Supp. 3I7, 3x9-20
} (rgI6), aff'd on the opinion below 225 N.Y. 698 , I22 N.E. 880 (I9I9). 
stated that he wanted to talk with Gidden about a draft which was due that day, and was informed that Gidden had left for the day but would be in his office the following morning.

The following day the draft was presented several times at Gidden's office and payment demanded, which Gidden refused to make, without assigning any reason other than that he had intended to ship part of the salmon to Porto Rico and that, owing to his inability to get the receipt in due time the day before, he had been unable to make the shipment.

Later, the Bank sold the salmon at public auction, applied the proceeds in part payment of the draft, and then sued Gidden to recover the difference between the amount due on the draft and the amount of the proceeds of sale.

Gidden set up as defenses I) that he had, on December 23, I9I4, offered to pay the draft and demanded the delivery of the warehouse receipt, and that this offer and delivery were refused; and 2) that he had an order from a Porto Rico customer for 2,000 cases of the salmon which he had been unable to fill because he could not get the warehouse receipt on December 23 .

He also based a counterclaim on the fact that he had paid the freight at the time he had accepted the draft. This counterclaim may quickly be dismissed. A counterclaim must be based on a wrongful act of the opposing party. There was no wrongful act about the freight by the Bank, or X, its representative. On the contrary, Gidden had in the Gorman-Gidden contract undertaken to pay the freight. So that Gidden was claiming that Gidden's performance of Gidden's promise to Gorman was a wrong by Gorman. Silly.

On the main question, the court held that the failure of $\mathrm{X}$ to produce the warehouse receipt was no defense, but also said that it might have been the basis for a counterclaim (if such counterclaim had been made). I have already said ${ }^{28}$ that I think that it thereby gave a beacon light of which all mariners should take advantage.

We now come to the third point on which I am unable to agree with $\mathrm{Mr}$. Williston. He contends that the result reached was the proper result if the case presented a problem in the law of sales (as he contends) as contrasted with a problem in the law of pledge (as I contend). In one of our talks about this I said to him, "You knock Humpty Dumpty down, and then you set Humpty Dumpty up again. I have even more difficulty in 
following you when you set Humpty Dumpty up again than when you knock Humpty Dumpty down."

He contends: I) that it is not entirely clear that the Bank did not make a proper tender of the warehouse receipt on December 23, and 2) that in any event the Bank had made a proper tender on December 24 and that the slight delay of one day should, as matter of law, be held to be immaterial.

I submit that neither of these contentions merits support:

I) The draft was a negotiable instrument, and it should have been presented within banking hours, which end at three o'clock. Moreover, Gidden had already tried to pay and there was no reason why he should be under a duty to the Bank to stay in his office after three o'clock if he wanted to go elsewhere. Moreover, I have difficulty in treating the telephone conversation which took place shortly before four o'clock as amounting to a presentment of the draft to Gidden.

2) It may well be that Gidden's story about his Porto Rico order was just a story, but $I$ have the greatest difficulty in seeing how a court could be justified in so ruling as a matter of law. The proper basis for curtly rejecting the Porto Rico story is that it was only a basis for a counterclaim, not a defense, and that Gidden's counsel had been so lacking in alertness that he had tried to treat it as a defense, and not as a counterclaim.

But let us assume that it had been properly pleaded as a basis for a counterclaim; that Gidden had then offered evidence that he had made a contract with a Porto Rico buyer for 2,000 cases of salmon if it could be shipped from New York by a specified boat which left, at, say, three o'clock on December 23; that the failure of $X$ to produce the warehouse receipt had caused Gidden to miss the boat and so to lose the benefit of his Porto Rico sale; and that Gorman knew, when the Gorman-Gidden contract was made, that Gidden was buying for purposes of resale and that he had Porto Rico connections. I think it very unlikely that Gidden could have shown such facts, but I submit that it is clear that he should have been given a chance to do so, if he had pleaded a counterclaim.

Mr. Williston says, "Under the rule of Hadley v. Baxendale," damages due to the loss of a particular sale are not recoverable unless the contract is made with reference to the sale." ${ }^{30}$ The principle laid down in that oftcited case for measuring damages for a breach of contract is unexceptionable (although that principle has not infrequently been so misapplied to the facts of a particular case as to result in "sadly shrunken damages")..$^{3 x}$

But note, and note well, that there is a large body of authority that on

${ }^{29} 9$ Exch. $34 x$ (I854).

30 Williston, op. cit. supra note $x$, at 736 .

3x Warren, Margin Customers $139-47$ (r94r). 
such facts as have been assumed above, the damages for the breach of contract may include the loss of a sale. In the American Law Reports, Annotated, it is said:

The cases holding the seller liable for profits lost by the buyer where the latter is regularly engaged in the business of reselling goods of the kind covered by the sale contract, although no resale had actually been made at the time of the making of the principal sale contract, where the seller knew the nature of buyer's business and that the goods were purchased for resale, are not inconsistent with the foregoing principles. In that class of cases, it may be said that the resale, and the profits to be realized thereon, were within the contemplation of the parties at the time they contracted. According to those cases, knowledge of the intention to resell charges the seller with notice that a loss of profits will result from his breach of the sale contract. ${ }^{32}$

Some of the numerous cases supporting the text are mentioned in the footnote. ${ }^{33}$

A final word as to a minor point upon which there was no discussion in the report (probably because counsel for Gidden had not raised the point)-the court allowed interest on the deficiency. The propriety of that seems to me to be doubtful.

Where there is breach of a promise to pay money, interest at the legal rate is ordinarily allowed as damages for the delay. But if $\mathrm{X}$ had not carelessly mislaid the documents, Gidden would have paid on December 23 . It is true that on December 24, the Bank, through $\mathrm{X}$, made a proper demand and tender, and Gidden then refused to pay, and that such refusal was neither justifiable nor excusable. It is true that Gidden was mistaken as to his rights and slipped, but $\mathrm{X}$ had greased the way.

It seems to me that the better disposition of the matter would have been not to allow interest on the deficiency. I am the more inclined to that view because it was really pretty bad for $\mathrm{X}$ (the Irving National Bank) not to know on December 23 where the drafts were which it was its duty to its client to present that day. I do not think that the Bank

3288 A.L.R. I439, 1467 (1934).

33 Johnson v. Hislop, 272 Fed. $9{ }_{3}$ (C.C.A. gth r92x); Border City Ice \& Coal Co. v. Adams, 69 Ark. 219, 62 S.W. 59I (rgor); J. P. Smith Shoe Co. v. Curme-Feltman Shoe Co., $7 x$ Ind. App. 40I, Ix8 N.E. 360 (19I8); Bluegrass Cordage Co. v. Luthy \& Co., 98 Ky. 583, 33 S.W. 835 (1896); Roberts, Wicks \& Co. v. Lee, 125 Ky. 709, 102 S.W. 300 (rgo7); Harrow Spring Co. v. Whipple Harrow Co., 90 Mich. I47, 5 I N.W. 197 (1892); F. W. Kavanaugh Mfg. Co. v. Rosen, $\mathrm{r}_{32}$ Mich. 44, 92 N.W. 788 (rgo2); Crystal Springs Ice Co. v. Holliday, I06 Miss. 714, 64 So. 658 (1914); Punteney-Mitchell Mfg. Co. v. Northwall Co., 70 Neb. 688, 97 N.W. I040 (I904); American Steel \& Wire Co. v. Copeland, I59 N.C. 556, 75 S.E. 1002 (I9I2); Eureka Producing Co. v. Hoyt, 266 S.W. 203 (Tex. Civ. App. x924); Sedro Veneer Co. v. Kwapil, 62 Wash. 385, Ir3 Pac. II00 (I9II); Raleigh Lumber Co. v. Wilson \& Son, 69 W.Va. 598, 72 S.E. $65 I$ (IgII). 
should be held liable as a converter because of the carelessness of $X$, its agent-it has, as $I$ have already said, ${ }^{34}$ been settled law for centuries that that kind of tort which is styled a conversion may never be based on carelessness; but I submit that it will be for the good of the business community if such a careless act is not treated as having no undesirable consequence, and the loss of interest strikes me as a fitting undesirable consequence for a court to impose.

\section{REJOINDER}

\section{SAMUEL WILLISTON*}

I DO NOT wish to make a prolonged argument regarding the difference of opinion between my friend and colleague Mr. Warren and myself on the law of pledge-the sort of difference that arises in every law faculty of thinking men-but I should like briefly to restate my position for the sake of clarification.

I. I agree with Mr. Warren that the pledgor's obligation to pay is absolute. I regret that he emphasizes the fact that in most cases the pledgor's promise is on a negotiable note. True as that doubtless is, the emphasis tends to obscure the fact that the obligation of a pledgor whose debt is not represented by a negotiable instrument is equally unconditional and absolute. Neither reason nor authority differentiates the cases.

2. When a promisor gives security, whether for the payment of money or for any other performance, there is a condition implied in fact that the obligation to return the security depends on the performance of the promise. The very words, security, collateral, pledge, contain that implication, and the parties so understand. In this case the promise is to pay. The parties do not bargain in regard to tender. Tender is a legal conception, excusing performance because one who refuses a proper tender prevents performance; and any kind of prevention has similar operation. Therefore, though the pledgee's promise to return the pledge is by the condition implied in fact dependent upon payment, its legal effect is, as Mr. Warren says, a promise to return not only if payment is made but also if tender of payment is made. Other qualifications of the pledgee's promise also exist, namely that return shall not be prevented by excusable impossibility or the right of a third person to possession. I regard all these excuses, like fraud, as imposed by the law irrespective of intention of the

34 Page 589 supra.

* Professor of Law Emeritus, Harvard University. 